\title{
液体バッグ積載時のコンテナ側壁の変形計測
}

\author{
三田 重雄* ・庄司 邦昭**
}

\section{Measurement of bulge of container loaded with liquid bag}

\author{
Shigeo MITA and Kuniaki SHOJI, Jiro YAMADA, Kohtaro TANAKA
}

\begin{abstract}
The liquid transportation uses a tank container, recently a new method to transport the bag which filled with liquid with the container was carried out experimentally. But, bulge or strain of the wall which loaded with liquid bag onto a container are unidentified. In this study, the authors used the $20 \mathrm{ft}$ container and filled the bag with water and measured the deformation and strain of the wall. As a result, a state of the bulge of the side wall became clear. The bulge of the wall was equal to or less than $18 \mathrm{~mm}$ at the center of the container and clear that it was the transformation of the tolerance level. In addition, change of the strain and the influence of the acceleration became almost clear, too.
\end{abstract}

Keywords : Container, Liquid bag, Bulge, Wall キーワード：コンテナ，液体バッグ，変形，壁

\section{1. はじめに}

液体輸送には陸上、海上ともアルミや銅板ででき た円筒形の専用タンクを使うのが一般的で、タンク の内部には自由水影響を低減するために防波板が設 けられている。これに対し、水を封入したバッグを 船倉に積み込んで船舶で輸送する方法が西野ら に゙ よって提案され、基礎研究が行なおれている。また、 巨大な液体バッグを使ってコンテナ輸送する方法も 始まった。バッグ輸送では静水圧や自由水による変 動荷重に耐え、液漏れを生じないことが重要である。

本研究で対象とするコンテナ輸送ではバックの強 度をコンテナの強度で補う方法がとられ、持ち帰り が不要な使い捨て式の樹脂製バックをコンテナに積 載した後に液体を注入する。この場合、コンテナに 大きな変形が生じるが塞態が把握されてお就ら゙、規 格化されたコンテナを積載するコンテナ船での運用 が滞っている。ここではコンテナに液体バッグを積 載した時の壁面の変形挙動を、実機を使用して大井 コンテナターミナルにおいて注水作業と移動実験、
ならびに排水作業を行って調査した一例を報告する。

\section{2. 研究の方法}

\section{1 コンテナおよび液体バッグ}

実用化されている液体バッグの多くは、20フィー トコンテナ (以下 “20ft”) 用で、実験では 20ft、24ton 型のコンテナと、最近製品化された小川テック製の $20 \mathrm{~kL}$ 型液体バッグ（商品名“シルキー”）を使用し た。24ton 型コンテナは旧型で、側壁のコルゲーシ ヨンの形状は大半を占める現行の 30ton 型の連続し た台形と一部が異なり、三角形の部分（Fig. 1 参照) がある。一方、液体バッグは厚さ $0.5 \mathrm{~mm}$ で $3850 \mathrm{~mm} \times$ $6650 \mathrm{~mm}$ のポリエチレンフィルム 2 枚を枕状に熱融 着してポリプロピレンの不織布で覆ったもので、膨 らました時の中央円形断面直径はコンテナの公称内 法高さ $2387 \mathrm{~mm}$ （幅 $2352 \mathrm{~mm}$ ）に等しい。なお、コ ンテナ内のささくれや突起物から保護するために床 面と側面にダンボールを敷く等養生法が決められて いるが、製品は 1 回限りの使用に限定されている。

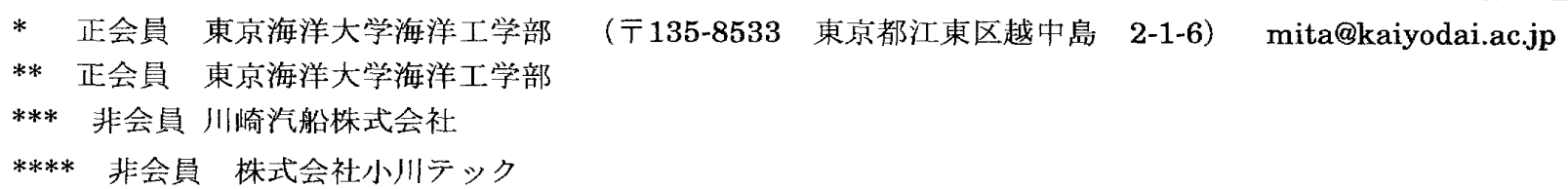



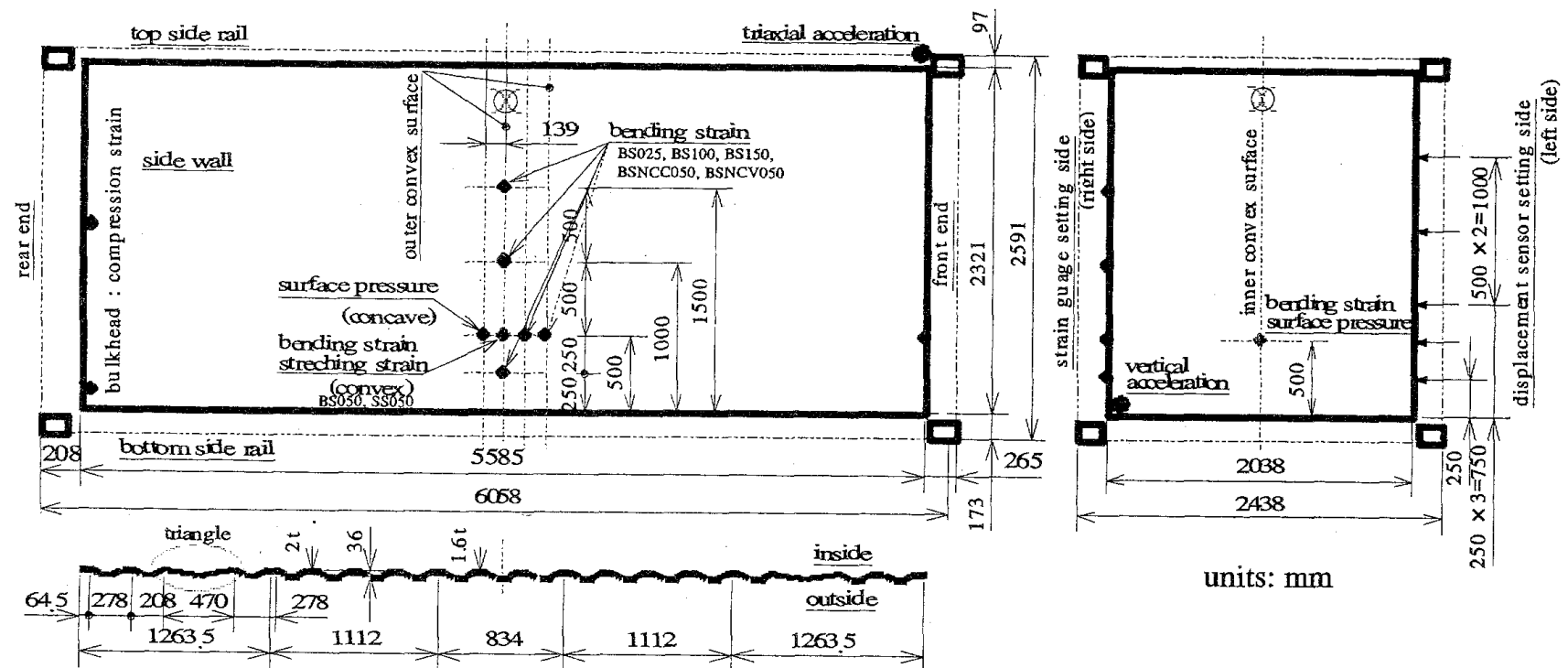

Fig. 1 Dimensions of $20 \mathrm{ft}$ container and arrangement of sensor setting points.

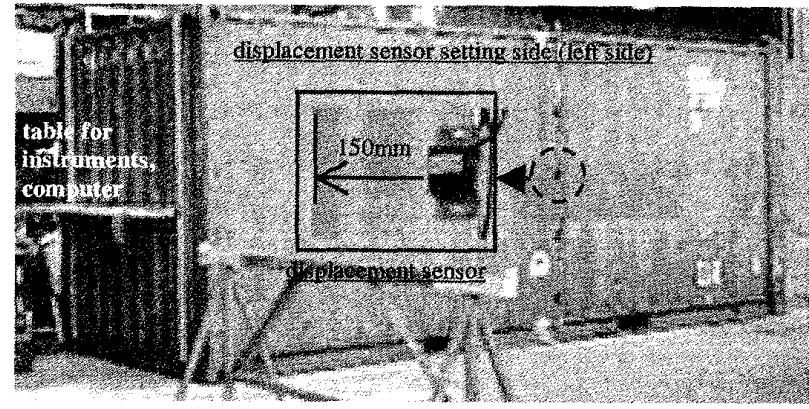

Fig. 2 General view of container, and displacement sensor

\section{2 実験の方法}

実験は注水および排水、テナークレーンによる上 下・左右方向の移動および積み重祆、ならびにヤー ドトラックに積載してのヤード周回を行い、この間 の壁面の変形やひずみ、壁面に加わる圧力、コンテ ナ本体に作用する加速度等の変化をセンサーで計測 した。また、注水および排水の前後に側壁の凸部に スケールを当てて両面全体の高低差を測定し、壁面 の変形状態の変化を調べた。Fig. 1 に 20ft コンテナ の寸法とセンサー類の配置を、Fig. 2 に実験準備中 のコンテナ外観と変位計の取り付け状態を示す。な お、コンテナは加工を行うために実験に支障がない 程度の変形や傷が残る要修理品を使用したが、実験 に先立って目視を行い、側壁の変形が少ない右側を ひずみ計測面、左側を変位計取り付け面とした。

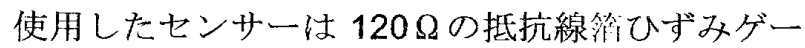
ジ（共和電業：KFG-3-120-C1）とひずみゲージ式 の圧力計 (共和電業: PS-05KD、定格容量 $50 \mathrm{kPa}$ )、 単軸加速度計 (共和電業: SA-10B、定格容量 10G) 、 三軸加速度計 (共和電業: AS-2TG、定格容量 2G) 、 ならびにレーザ光式の変位計（SUNX：LM10-130、 測定中心距離 $130 \mathrm{~mm}$ 、測定範囲 $\pm 50 \mathrm{~mm}$ ) で、ひず みゲージは壁面の内と外の同位置に貼り付けて曲げ
ひずみ（略記号“BS”）と引張ひずみ（略記号 “SS”） が検出できるようにした。なお、バッグと壁面の中 間には養生用の厚さ $5 \mathrm{~mm}$ の段ボールが挟まれてお り、センサーは直接接していない。また、変位計は Fig. 2 の写真に示すように変形を見込んで壁の表面 から約 $150 \mathrm{~mm}$ 離して鋼製アングルに取り付けた。 そして、注・排水時や実験中の計測信号はデータ収 録器（KEYENCE：NR-2000）を使ってパソコンに 収録し、解析に供した。これらの計測器やパソコン 等はコンテナの前側（front end）に仮設した台に配 置し、電源は小型発電機とバッテリーから供給した。

これに対し、壁面全体の変形は鋼製アングルにデ プスゲージ式のスケールを $150 \mathrm{~mm} \sim 250 \mathrm{~mm}$ 閒隔で 取り付けた手持ち式の形状測定治具を使い、上下の はりの表面を基準にして外側凸面の中央付近の高さ を測定した。測定治具を横にした状態を Fig. 3 に示 すが、スケールの読み取り基準線は平面に対し絶対 誤差が $1 \mathrm{~mm}$ 以下になるように設けてあり、治具の 精度と押し当てるはりとの接触状態も含めた絶対誤 差は基準平面に対し $2 \mathrm{~mm}$ 以下と考えられる。

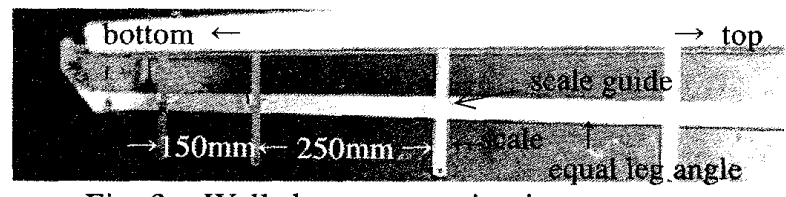

Fig. 3 Wall shape measuring instrument.

\section{3. 結果および考察}

\section{1 注 - 排水による壁面全体の変形}

バッグへの注水作業はコンテナをヤードトラック に載せて台科の上で行い、所定の 20ton を注水して 満水にした。所要時間は給水ホースの調整も含める と 2 時間半以上に及んだ。Fig. 4 に別の機会に撮影 


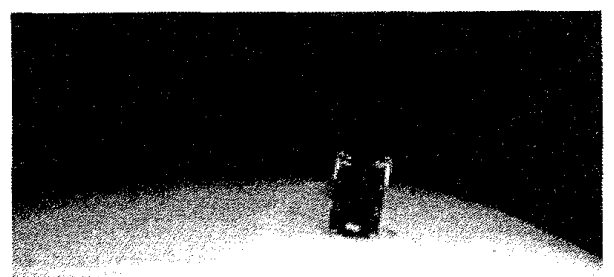

Fig. 4 Shape of a bag filled with water.

した満水時の液体バッグの椂子を示す。詳細な形状 はつかめないが、おおむ秋枕状に膨らんで上方が潰 れていることが分かる。センサーを使った変形挙動 の計測結果は後述することとし、スケールを当てて 測定した壁面全体の形状変化について先に述べる。

Fig. 5 と 6 は右側と左側の壁面について、注水の 前後に測定した凸面の等高線図とこれらの差から求 めた変形量の等高線図を示す。横軸が屝側を0とし たコンテナの長さ方向、縦軸が下側を０とした高さ 方向の位置で、左側の中央は変位計が取り付けてあ るために両脇の值を平均した值で表した。

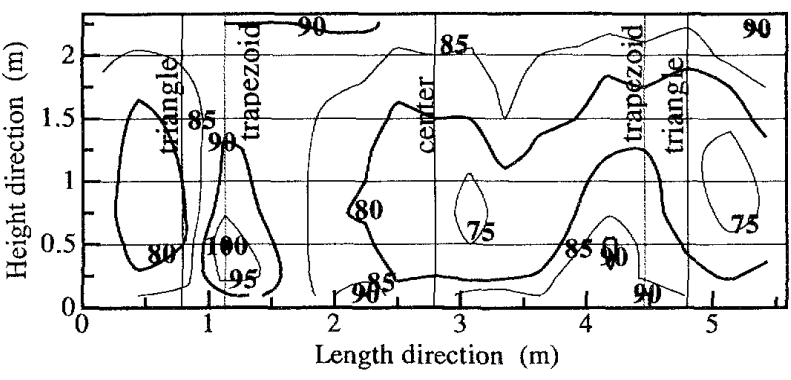

a. Before supply with water.

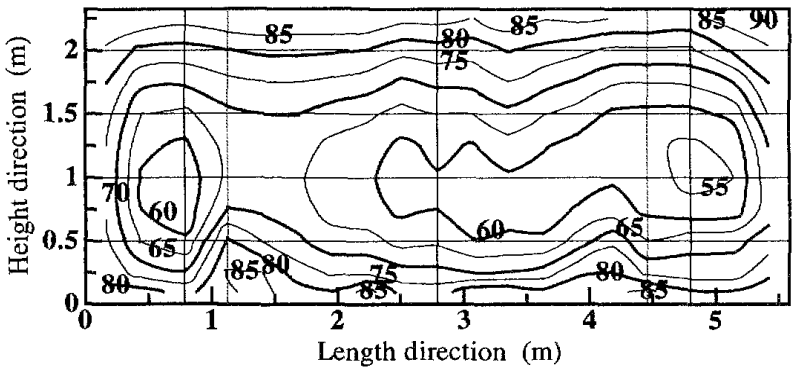

b. After filled with water.

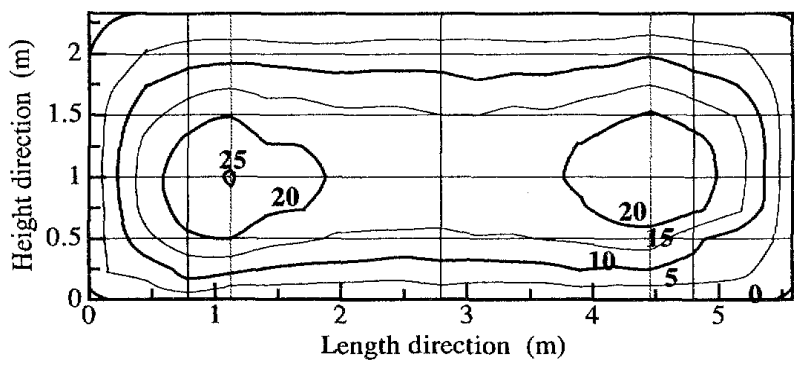

c. Bulge of wall.

Fig. 5 Contour map of wall of right side. a に示寸注水前の壁面の等高線は右側が $75 \mathrm{~mm}$ $100 \mathrm{~mm}$ 、左側が $80 \mathrm{~mm} \sim 100 \mathrm{~mm}$ の範囲に分布して おり、測定治具の測定誤差以上の有意な変化である。 そして、縦線で示す中央と前後端のコルゲーション が三角形を成している付近（以下 “三角形部”）、左 側の屝側から $2.2 \mathrm{~m}$ と $3.9 \mathrm{~m}$ 付近に変形があり、平坦 でないことが分かる。次の $\mathrm{b}$ 注水後の等高線で、 左右面とも中段付近が前・後部端を除いてほぼ均一 に膨らんでおり、中央と前・後端の三角形部の膨ら みが幾分大きい。最後のc 注注水後の值から注水前 の值を差し引いた注水による変形量の等高線で、左 側、右側とも前・後端の三角形部中段付近の変形が 大きく、一部で $20 \mathrm{~mm}$ 以上に達しているが概ね似通 った変形を示している。そして、上下、前後端に近 付くほど小さくなっており、左側の三角形部脇に 25 $\mathrm{mm}$ を超えた点があるが、コルゲーションの形状が 均一な台形で、現行の 30ton 型と同一形状である中 央付近（中央のパネルは板厚 $1.6 \mathrm{~mm}$ ）の変形は 15 $\mathrm{mm}$ と $20 \mathrm{~mm}$ の等高線の範囲内に収まっている。ま た、中段付近（下端から約 $1 \mathrm{~m}$ の高さ）で側壁の変

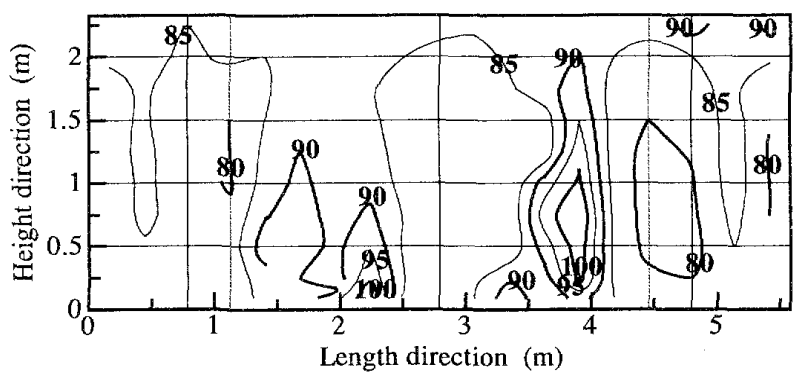

a. Before supply with water.

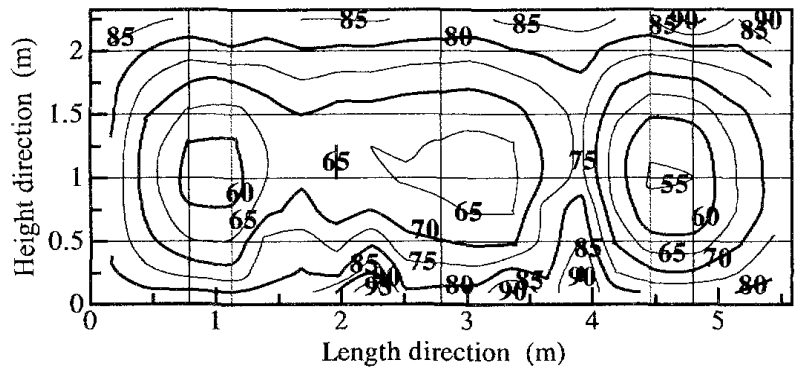

b. After filled with water.

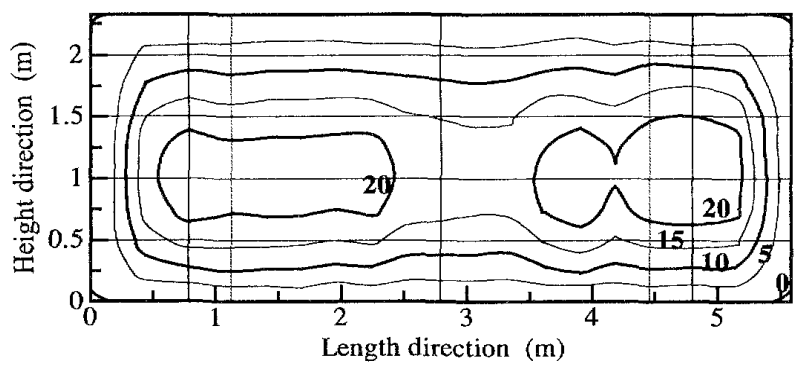

c. Bulge of wall.

Fig. 6 Contour map of wall of left side. 
形が最大になっているが、この要因として、バッグ はFig. 4 に示したように枕状に膨らむが、水の重さ で変形して中段付近の広い範囲で側壁に接している ことが考えられる。

次に、後述するヤードトラックによる周回実験を 終了した後に計測した壁面の凹凸と、排水を完了し て4日間経過した後に計測した壁面の凹凸から求め た排水時の変形（戻り量で表す）を Fig. 7 に示す。 また、Fig. 8 に注水前と排水 4 日後の壁面の咱凹か ら求めた壁面の残留変形を示す。Fig. 7 の右側の変 形は注水時と似通った等高線を示していて、Fig. 8

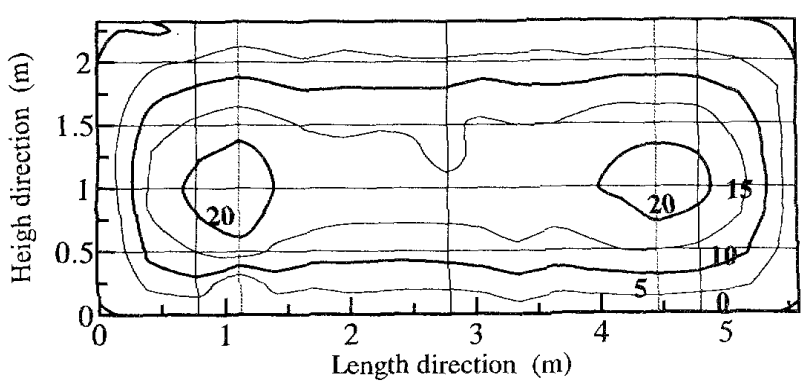

a. Right side.

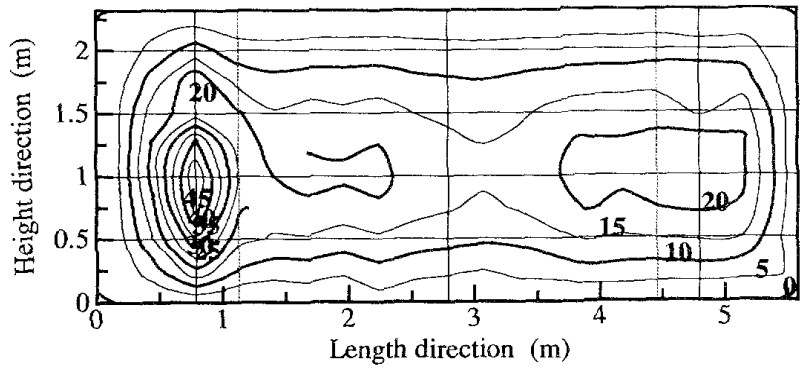

b. Left side.

Fig. 7 Spring back of wall after drainage.

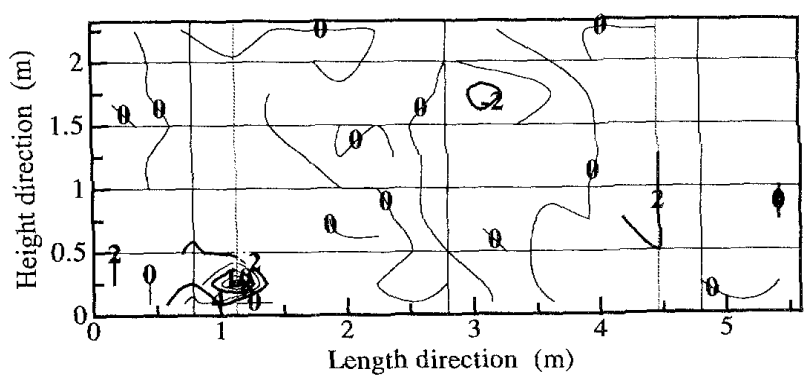

a. Right side.

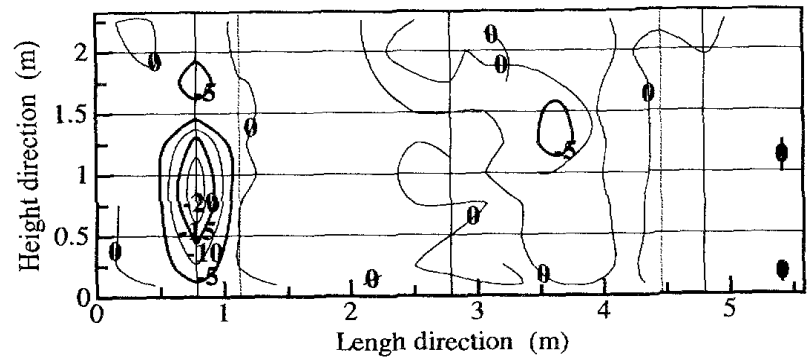

b. Left side.

Fig. 8 Remaining deformation of wall after tests.
の、に示す残留変形もほとんどが 0であり、液体バ ッグによる一時的な変形はほぼ完全に回復している。 一方、Fig. 7 のbに示守左側は、扉側に近い三角形 部で注水時よりも等高線が高くなっていて、Fig. 8 の残留変形もこの部分だけに大きく変形（くぼみ） を生じた状態になっている。この原因は排水後のコ ンテナをメンンテンスショップ周边で大型フォーク リフトを使って数回移動していることから、実験後 に変形したと考えられ、バッグを積載した際の変形 は回復している。

\section{2 注・排水時の壁面の変形挙動}

Fig. 9に給水前の初期状態から給水が完了するま で続けて収録した時系列データの収録画面を示す。 画面上段から中段はひずみと生力、下段は変位計で 検出した壁面の変形で、横方向加時間軸、繸方向が 変動（ここでは電圧）を示して掞り、注水によるは っきりとした変動は収録開始から1/3 位時間が経過 した時点から認められる。当初、壁面全体に水圧が 作用すると見込んでひず办計やデータ収録器の感度 を設定したので画面上の変動は小さく表示されてい るが、長時閒の変動が取得できた。これに対し、Fig. 10 に実験終了後の約 20 分間の排水時の時系列デー 夕を示すが、給水時よりす感度を上げたので変動が 十分に認められる程度の大きさで取得できた。当初 バルブから徐々に排水を行なったが、途中でバッグ を切り裂いて短時間で完了させたのでその変動も中

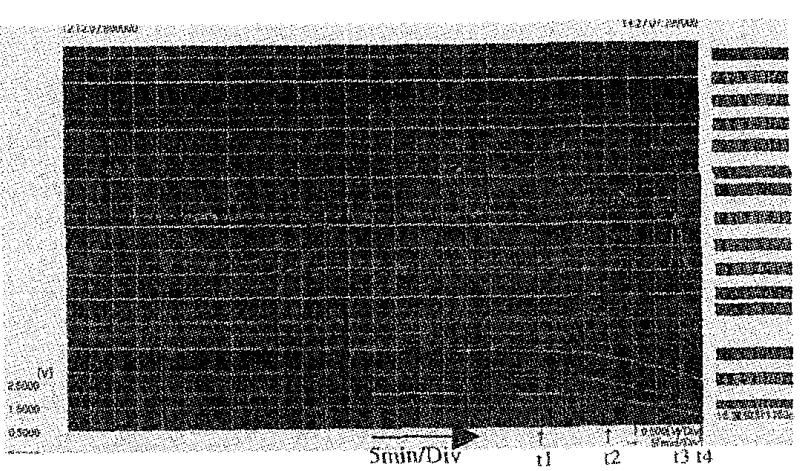

Fig. 9 Time history on pouring water.

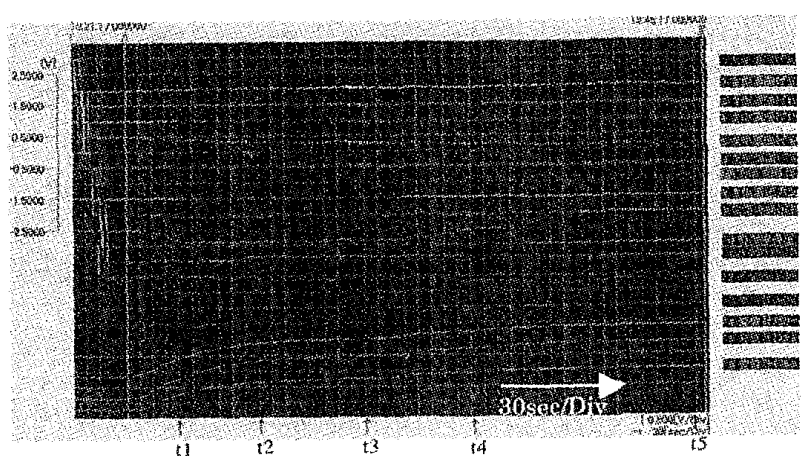

Fig. 10 Time history on pump out. 
盤に現れている。また、引張ひずタはスケールアウ トしないように途中で感度を切り替えた。なお、Fig. 9、10 とも注水量、あるいはバッグの膨らみとの関 係は得られていないが、注水が進んでバッグが側壁 にもたれ始めてからひずみに変動が生じていると考 えられる。

次に、Fig. 11 に注水時の時系列データについて壁 面の変形挙動と主要なひずみの変化を解析した結果 を示し、Fig. 12 に排水時の解析結果を示す。

Fig. 11 の a は左側壁面の凸部中央に取り付けた変 位計で計測した注水中の膨らみ量の変化で、変動を 生じてから約 15 分間隔（Fig. 9 に t1〜 t4 で示す) で測定した注水完了までの変化を示す。図は横朝が 変形（膨らみ）量、縦軸が高さ方向の位置（h）で、 いずれの時間においても下から $1 \mathrm{~m}$ 付近が最大を示 す放物線状になって徐々に膨らみ、最大でも $18 \mathrm{~mm}$

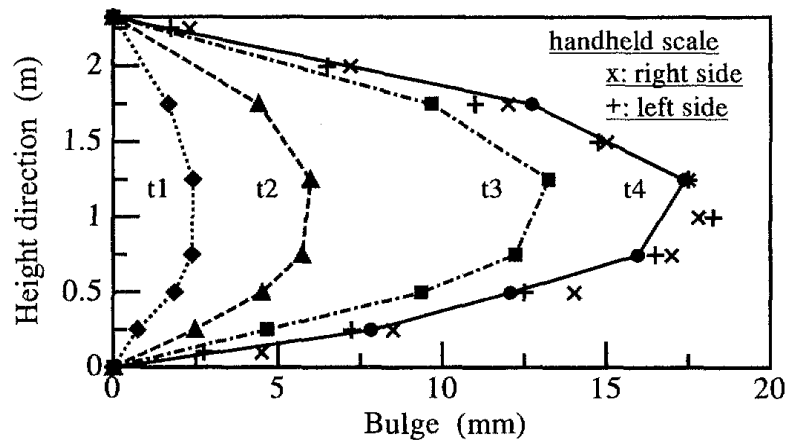

a. Bulge of wall.

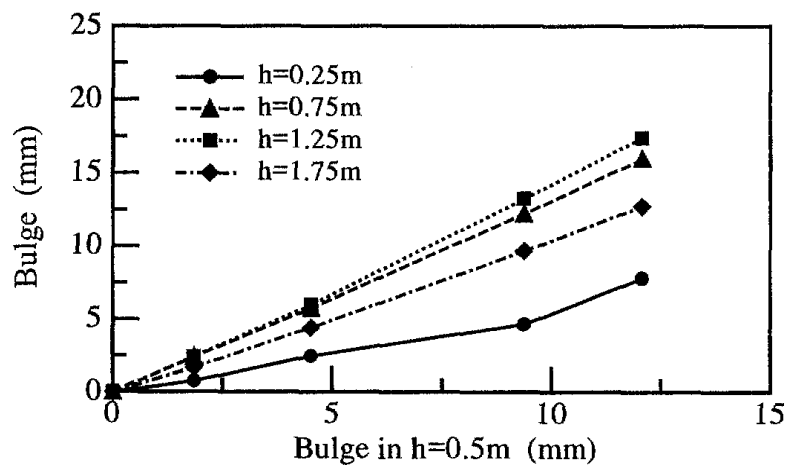

b. Change of deformation of wall.

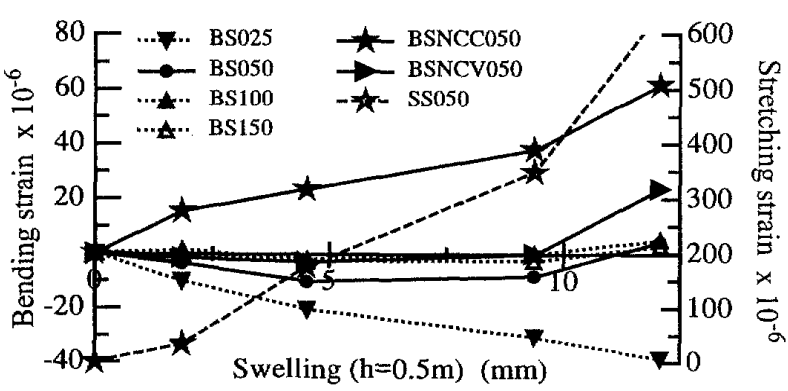

c. Change of strain.

Fig. 11 Deformation behavior of wall on filling.
には達していない。网には注水後の変形量について スケールを当てて測定した右側中央の値をメ印、左 側の変位計取り付け部の両脇の平均值を十印で示す が、変位計で検出した值と一致しており、左右対称 に変形が進んでいる。同様に Fig. 12 の a に排水時 の変位計で検出した凸部の変形（㞔り）量と Fig. 11 に示した注水時の変形、ならびにスケールを当てて 測定した値を示す。このときの時系列值の読み取り 間隔は約 4 分（Fig. 9 に $\mathrm{t} 1$ ～t5 で示す）であるが、 変形挙動は注水時と同様で、大きさも排水完了時の 戻り量と注水時の膨らみ量とがほぼ一致しており、 変形は回復している。なお、排水後にスケールを当 てて測定した右側の高さ $1.25 \mathrm{~m}$ 点の值だけが $10 \mathrm{~mm}$ 小さくなっている（これは読み取りミスも考えられ る）が、他の值は注水時と同様に変位計で検出した 值と一致している。

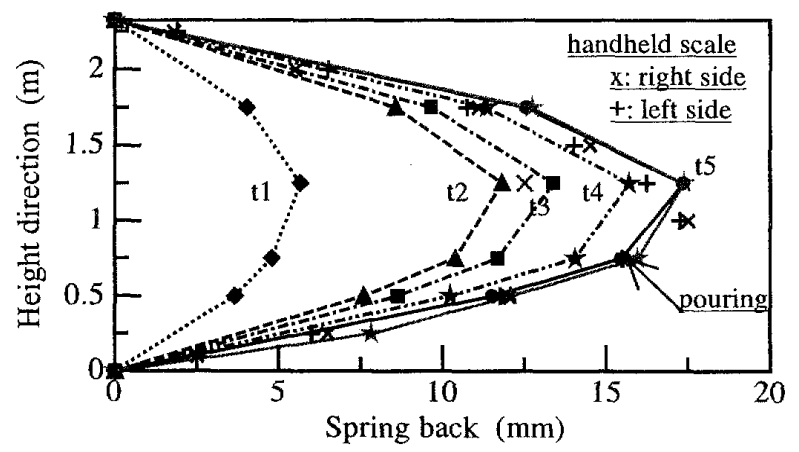

a. Spring back of wall.

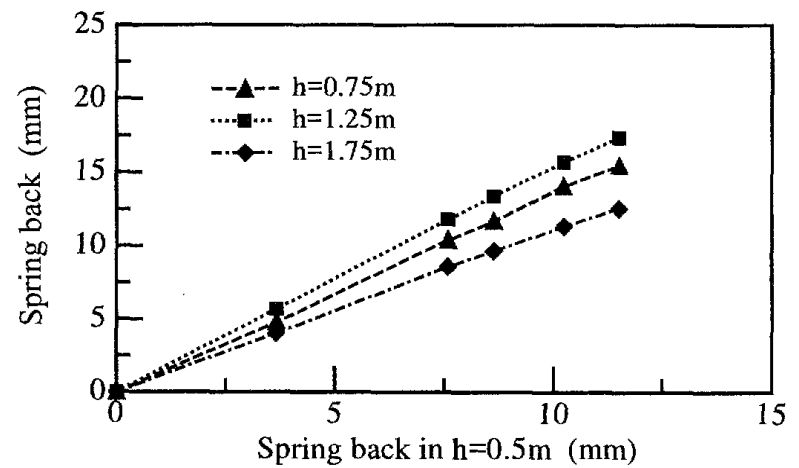

b. Change of deformation of wall.

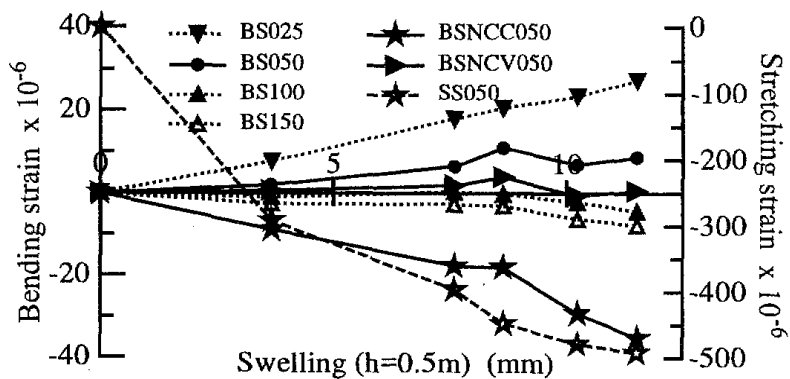

c. Change of strain.

Fig. 12 Deformation behavior of wall on draining. 
Fig. 11、12のb、c は $\mathrm{h}=0.5 \mathrm{~m}$ における変形量に 対する他点の変形、ならびにひずみの関係を調べた ものである。b に示すように他点の変形は $h=0.5 \mathrm{~m}$ における変形に比例して注水時は膨らみ、また排水 時は戻っており、相関があることが分かる。また、c に示すひずみの変化は、変動の小さい計測点もある が、注水時と排水時とではひずみの方向がすべて逆 向きになっているので有意な変化であると考えられ る。そして、、印で示す $h=0.25 \mathrm{~m}$ での曲げひずみ （BS025）、 太印で示す中央脇の凹部 $\mathrm{h}=0.5 \mathrm{~m}$ での曲 げひずみ（BSNCC050）、约印で示す引張ひずみ （SS050）は、壁面の変形にほぼ比例して注・排水 後に $20 \times 10^{-6}$ st $\sim 600 \times 10^{-6}$ st 程度の変化を生じてい る。中でも引張ひずみは大きく、給水時が $600 \times 10^{-6} \mathrm{st}$ 、 排水時が-500×10-6 st 程度に達しており、曲げひずみ も計測位置によって極性が異なる等、変形挙動を予 測する上で重要な手がかりになると考える。

このひずみを応力に換算すると、

$\sigma=\mathrm{E} \cdot \varepsilon$

ここで

$\mathrm{E}:$ 緃弾性係数 $\quad\left(=205.8 \mathrm{kN} / \mathrm{mm}^{2}\right)$

ย：ひずみ

$\sigma:$ 応力 $\left(\mathrm{kN} / \mathrm{mm}^{2}\right)$

であるから、 $\varepsilon=600 \times 10^{-6}$ st としたときの引張応力 は式(1)から $0.123 \mathrm{kN} / \mathrm{mm}^{2}$ となる。この值は一般構 造用压延鋼材 (JIS SS400) の降伏応力 $0.245 \mathrm{kN} / \mathrm{mm}^{2}$ の半分程度に当たる。なお、コンテナに使用されて いる高耐候性圧延鋼材(2)コールテン (JIS SPA-H 相 当)の降伏応力は $S S 400$ よりも高く、0.343 kN/mm² に達し、より安全である。そして、実験で計測した 範囲では曲げひずタは引張ひずみよりも 1 桁小さい が、計測位置によって異なるので計算等により変化 を確認する必要がある。なお、国際一般貨物コンテ 大(3)（JIS Z-1618）側壁全面に垂直外向きに最大積 載質量の 0.6 倍の荷重をかけて試験（強勒な風船を 膨らませて加圧する $\left.{ }^{(4)}\right)$ され、荷重が取り除かれた 後に使用上の妨げとなるような変形または損賃があ ってはならないとされている。某検查機関で沬最大 でも残留変形は中段部で $12 \mathrm{~mm}$ 以内、上部、下部で $3 \mathrm{~mm} 、 5 \mathrm{~mm}$ 以内の判定基淮が設定されている。今 回の実験では静水圧による側壁中央部の変形は 18 $\mathrm{mm}$ 近くに達したが、積み付计に支障をきたす 25 $\mathrm{mm}$ には至らず、前述したように排水後に回復した。

\section{3 壁面の変形量の試算}

ここでは液体バッグが無くて静水圧が壁面に分布 して作用する場合と、Fig. 11 と Fig. 12 の結果から
下から $1 \mathrm{~m}$ の高さに集中荷重が作用する場合の壁面 の変形について、壁面の中央部分を単純な両端固定 または単純支持のはりと考えて変形挙動を調べる。

Fig. 13 に側壁の中央パネルの断面形状と分布荷重、 集中荷重の 2 種類の異なるはりを示すが、ここでは a の図に示すパネルの断面寸法は内側と外側の平面 部分を括弧で示す值とし、1 ピッチ $278 \mathrm{~mm}$ 当たり の断面諸量を次式のより計算した。ただし、A：断 面積、I : 断面二次モーメント、 $\mathrm{Z}$ : 断面係数

$$
\begin{aligned}
& A=2 \cdot t(a+b) \\
& I=2 \cdot \frac{t \cdot d^{2}}{12}(3 \cdot a+b) \\
& Z=2 \cdot \frac{t \cdot d}{6}(3 \cdot a+b)
\end{aligned}
$$

先ず、静水圧が壁面に作用する場合について調べ る。このコンテナの公称内法寸法高さ $5901 \mathrm{~mm} \times$ 幅 2352mm であるから、20tonの清水を満たしたと きの水面高さは $20 \times 10^{3} /\left(5901 \times 2352 / 10^{6}\right) \fallingdotseq 1441 \mathrm{~mm}$ となる。また、側壁のパネルの高さと長さは Fig. 1 に示したように $2321 \mathrm{~mm} \times 5585 \mathrm{~mm}$ で、床面とパネ ルの下部とは一致しているとする。

ここで、両端固定のはりに分布荷重 $w_{0}(\mathrm{~N} / \mathrm{mm})$ または集中荷重Wが作用したときとの反力 $R_{1} 、 R_{2}$ 、 モーメント $M_{1} 、 M_{2}$ 、上端から $\mathrm{x}$ 離れた点にお汀る モーメント $M$ 、変形量 $y_{1} 、 y_{2}$ を文献(5)の公式で示す。

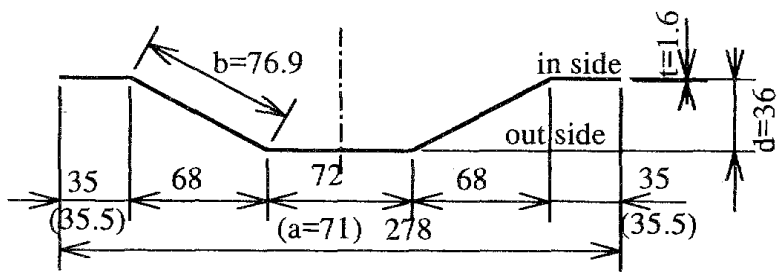

a. Cross section of side panel.
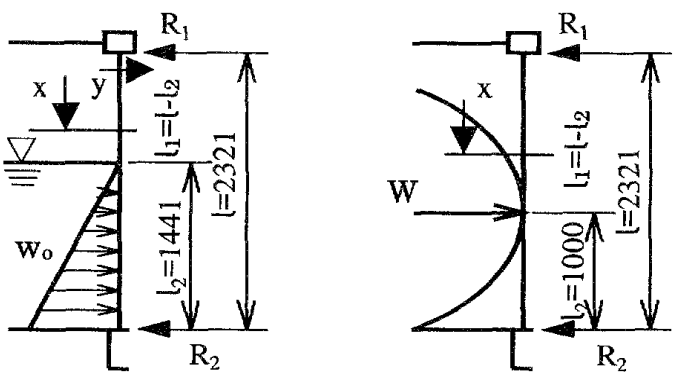

b. Hydraulic loading

c. Concentric load

Fig. 13 Load to act on side wall.

先ず、分布荷重については式(3)〜(5)で示される。

$$
\begin{aligned}
& \mathbf{R}_{1}=\frac{\mathbf{w}_{0} \cdot \mathrm{l}_{2}{ }^{3}}{4 \cdot l^{2}}-\frac{\mathbf{w}_{0} \cdot \mathrm{l}_{2}{ }^{4}}{10 \cdot l^{3}} \\
& \mathbf{R}_{2}=\frac{\mathbf{w}_{0} \cdot \mathrm{l}_{2}}{2}-\mathbf{R}_{1}
\end{aligned}
$$




$$
\begin{aligned}
& M_{1}=\frac{w_{0} \cdot l_{2}{ }^{3}}{12 \cdot l}-\frac{w_{0} \cdot l_{2}{ }^{4}}{20 \cdot l^{2}} \\
& M_{2}=M_{1}+\frac{w_{0} \cdot l_{2}{ }^{2}}{6}-R_{1} \cdot l \\
& 0 \leq x \leq l_{1}: M=-R_{1} \cdot x+M_{1} \\
& l_{1} \leq x \leq l_{1}+l_{2}: M=\frac{w_{0}}{6 \cdot l_{2}}\left(x-l_{1}\right)^{3}-R_{1} \cdot x+M_{1}
\end{aligned}
$$

$0 \leq \mathrm{x} \leq \mathrm{l}_{1}$

$$
\mathrm{y}_{1}=\frac{1}{\mathrm{E} \cdot \mathrm{I}}\left\{-\frac{\mathrm{R}_{1} \cdot \mathrm{x}^{3}}{6}+\frac{\mathrm{M}_{1} \cdot \mathrm{x}^{2}}{2}\right\}
$$

$\mathrm{l}_{1} \leq \mathrm{x} \leq \mathrm{l}_{1}+\mathrm{l}_{2}$;

$$
\mathrm{y}_{2}=\frac{1}{\mathrm{E} \cdot \mathrm{I}}\left\{\frac{\mathrm{w}_{0}}{120 \cdot \mathrm{l}_{2}}\left(\mathrm{x}-\mathrm{l}_{1}\right)^{5}-\frac{\mathrm{R}_{1} \cdot \mathrm{x}^{3}}{6}+\frac{\mathrm{M}_{1} \cdot \mathrm{x}^{2}}{2}\right\}
$$

次に集中荷重について $(6)$ (8)に示す。

$$
\begin{aligned}
& R_{1}=\frac{W \cdot l_{2}{ }^{2}\left(l+2 \cdot l_{1}\right)}{l^{3}} \\
& R_{2}=\frac{W \cdot l_{1}{ }^{2}\left(l+2 \cdot l_{2}\right)}{l^{3}} \\
& M_{1}=\frac{W \cdot l_{1} \cdot l_{2}{ }^{2}}{l^{2}} \\
& M_{2}=\frac{W \cdot l_{1}{ }^{2} \cdot l_{2}}{l^{2}} \\
& M_{3}=-\frac{2 \cdot W \cdot l_{1}{ }^{2} \cdot l_{2}{ }^{2}}{l^{3}}
\end{aligned}
$$$$
0 \leq \mathrm{x} \leq \mathrm{l}_{1} \text { : }
$$$$
y_{1}=\frac{W \cdot l_{1} \cdot l_{2}^{2} \cdot x^{2}}{2 \cdot E \cdot I \cdot l^{2}}\left\{1-\frac{\left(l+2 \cdot l_{1}\right) x}{3 \cdot l \cdot l_{1}}\right\}
$$$$
l_{1} \leq \mathrm{x} \leq \mathrm{l}:
$$$$
y_{2}=\frac{W \cdot l_{1} \cdot l_{2}{ }^{2} \cdot x^{2}}{2 \cdot E \cdot I \cdot l^{2}}\left\{1-\frac{\left(l+2 \cdot l_{1}\right) x}{3 \cdot l \cdot l_{1}}\right\}+\frac{W\left(x-l_{1}\right)^{2}}{6 \cdot E \cdot l}
$$$$
l_{1} \geq \frac{l}{2} \text { のとき } x=\frac{2 \cdot l \cdot l_{1}}{l+2 \cdot l_{1}}: y_{1 \max }=\frac{2 \cdot W \cdot l_{1}{ }^{3} \cdot l_{2}{ }^{2}}{3 \cdot E \cdot I\left(l+2 \cdot l_{1}\right)^{2}}
$$$$
\mathrm{l}_{1} \leq \frac{\mathrm{l}}{2} \text { のとき } \mathrm{x}=\frac{\mathrm{l}^{2}}{\mathrm{l}+2 \cdot \mathrm{l}_{2}}: \mathrm{y}_{2 \max }=\frac{2 \cdot \mathrm{W} \cdot \mathrm{l}_{1}{ }^{2} \cdot \mathrm{l}_{2}{ }^{3}}{3 \cdot \mathrm{E} \cdot \mathrm{I}\left(\mathrm{l}+2 \cdot \mathrm{l}_{2}\right)^{2}}
$$

Fig. 13 の b示す両端固定のはりに静水压が作用 する状態について、式(3)〜(5)によりコルゲーション 1 ピッチ $278 \mathrm{~mm}$ 当りの計算をすると、反力 $\mathrm{R}_{1}=410$ $\mathrm{N} 、 R_{2}=2421 \mathrm{~N} 、$ 曲げモーメント $M_{1}=264.9 \mathrm{kN} \cdot \mathrm{mm}$ 、 $\mathrm{M}_{2}=672.8 \mathrm{kN} \cdot \mathrm{mm}$ となる。これを基に壁面の変形量 と曲げモーメントを計算した結果を Fig. 14 に太線 で示す。反力から長さ $5.585 \mathrm{~m}$ の壁面に加わる荷重 は $56.8 \mathrm{kN}(=(410+2421) / 1000 \times 5585 / 278)$ となり、

1 ピッチ $278 \mathrm{~mm}$ 当りの最大曲げモーメント $\mathrm{M}_{2}$ （最 下部の位置に作用する）から、最大曲げ応力 $\sigma_{\mathrm{b}}$ は

$$
\sigma_{\mathrm{b}}=\frac{\mathrm{M}}{\mathrm{Z}}
$$

により $0.121 \mathrm{kN} / \mathrm{mm}^{2}$ (断面係数 $\mathrm{Z}=5566 \mathrm{~mm}^{3}$ ) であ り、実験で計測された引張応力と同程度になる。実 験ではこの大ささに相当する曲げひずみは検出され なかったが、図にも示すように曲げモーメントが高 さ位置によって変化することも関係している。一方 壁面の変形を見ると、下から $1 \mathrm{~m}$ 付近が最大值 $3.6 \mathrm{~mm}$ に達するが、実験值の $20 \%$ 程度の大きさで ある。また、両端を単純支持のはりとした場合の計 算値を細線で示すが、下から $1 \mathrm{~m}$ 付近に最大変形量 $19.0 \mathrm{~mm} 、 0.8 \mathrm{~m}$ 付近に最大曲げモーメント $-772 \mathrm{kN}$. $\mathrm{mm}$ を生じ、変形量は実験值とほぼ等しくなる。

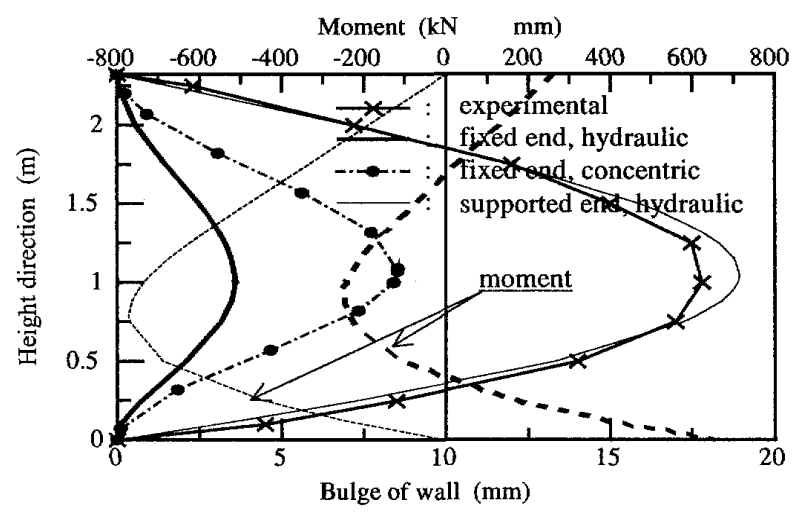

Fig. 14 Deformation of wall.

これらに対し、Fig.13のcに示す集中荷重の作用 する両端固定のはりに、高さ $1 \mathrm{~m}$ の位置に静水圧に 相当する単位幅当り10Nの集中荷重が作用したとき の変形量を式(6)～(8)で計算した結果を Fig. 14 に・ 印を付して示す。変形量の最大值は $8.5 \mathrm{~mm}$ で、ほ ぼ実験值の半分の大きさになっており、最大曲げモ 一メントが $913 \mathrm{kN} \cdot \mathrm{mm}$ 、曲げ応力が $0.162 \mathrm{kN} / \mathrm{mm}^{2}$ である。また、単純支持のはりとした場合の試算で は最大変形量 $34.2 \mathrm{~mm}$ 、最大曲げモーメント $1579 \mathrm{kN} \cdot \mathrm{mm}$ を生じ、大きい。

このように、はり両端の固定方法や荷重の加わり 方で変形量や曲げモーメントは大きく変わるが、液 体バッグを積載したコンテナではバッグが潰れ、高 さ $1 \mathrm{~m}$ 付近に広く壁面にもたれかかって静水圧相当 分が分布荷重となって作用し、荷重によってパネル を固定している上下端のサイドレールに稀じれ変形 が生じていると考えられる。したがって、液体バッ グの接触状態をつがことは不可欠であり、上下端 のサイドレールの変形も含め模型実験や数值解析に よって今後さらに調べていく必要がある。

\section{4 移動実験中の壁面の変形挙動}

テナークレーンとヤードトラックによる移動実験 時の時系列データの収録画面を Fig. 15、16に示す 


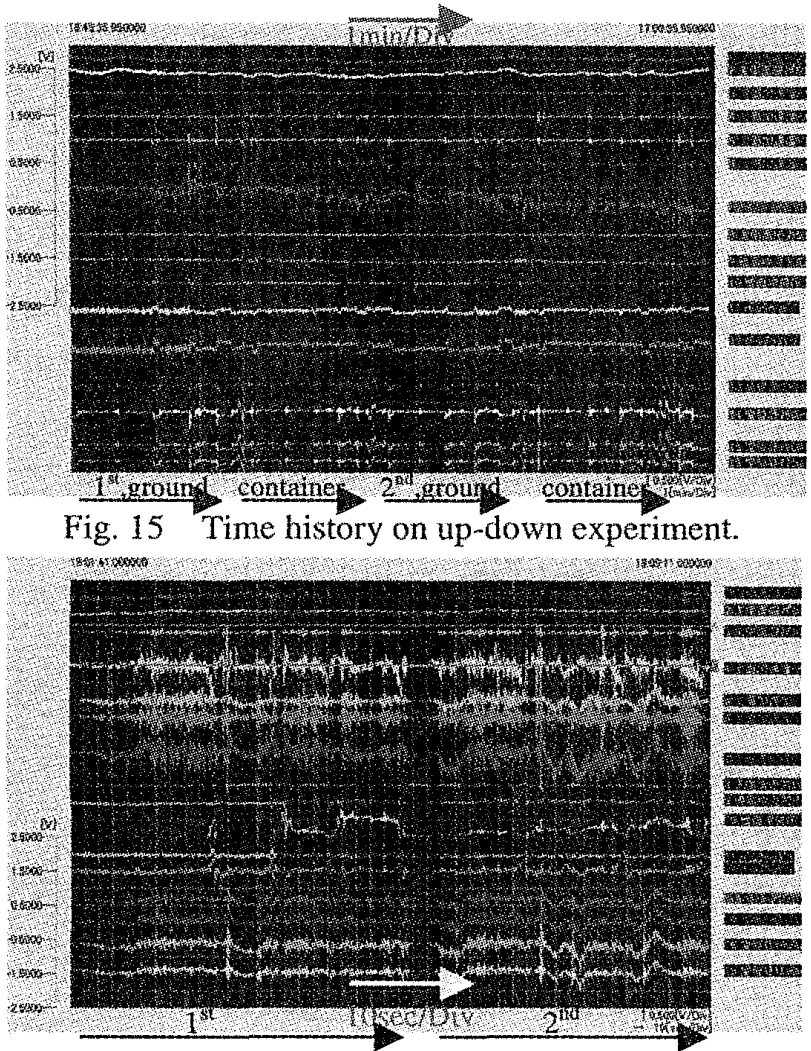

Fig. 16 Time history on circular experiment.

が、注水時とデータの収録項目を変更し、ひずみの 計测点を減らして新たに加速度を加えた。また、こ の実験ではひずみと圧力は実験前に初期平衡を取り、 静水圧分は除いた。

Fig. 15 はテナークレーンの上下スピードをコン トロールするノッチを 3 段階に変え、地上への上げ 下げとコンテナ上への積み重的を2回繰り返して行 った結果を示す。この実験では特にクレーンに取り 付けられているスプレッダーとコンテナの吊り金具 とに遊びがあり、地切りと着地の際に大きな衝撃が コンテナに伝わった。特徽のある時系列データを Fig. 17 に示すが、地切りと着地の際の衝撃がdのZ 方向の加速度の衝撃波形に連動して他のデータにも 現れている。そして、bとcの波形にはこれに合わ せて数箇所で0点の変動が見られる。これらを無視 するとZ方向の加速度の変化は $1 \mathrm{~g}$ 以下で、ひずみ や側壁の変形量等の変動分は静水圧による変化分の 数分の 1 であり、通常行うクレーンの操作範囲では コンテナの側壁に異常は生じないと予想される。

次に、Fig. 16 に示したヤードトラックの実験は液 体バッグを積み込んだコンテナをヤードトラックに 積載し、コンテナが蔵置されたヤードの一角（直線 距離約 $300 \mathrm{~m} 、 1$ 周約 $650 \mathrm{~m}$ ) を右回りで 2 周した もので、スタート直後に右旋回する。そして、20〜 $40 \mathrm{~km} / \mathrm{h}$ の速度で走行し、途中急ブレーキや道路上 に敷設された配管を乗り越える等を行ってデータを
取得した。旋回時や障害物を乗り越えるとき、ブレ 一キをかけたとき等に変動が出ているので特徴のあ る時系列データをFig. 18 に示す。

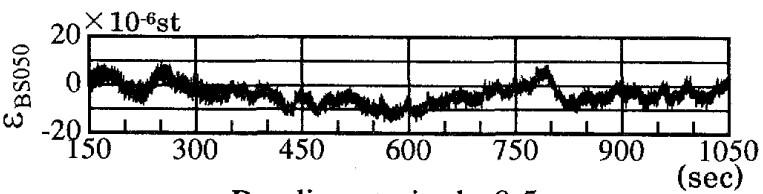

a. Bending strain, $\mathrm{h}=0.5 \mathrm{~m}$.

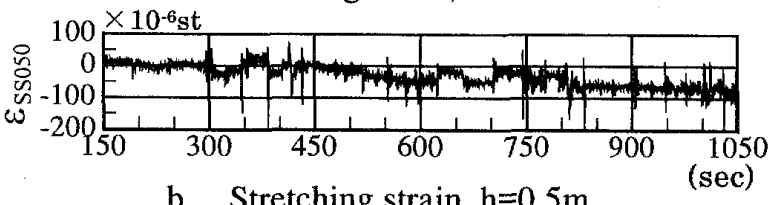

b. Stretching strain, $\mathrm{h}=0.5 \mathrm{~m}$.

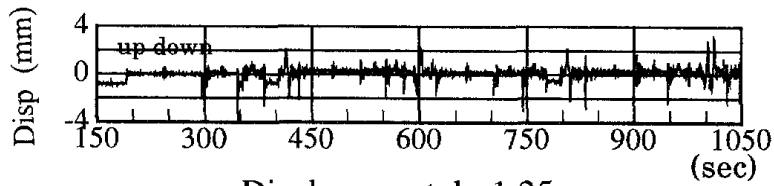

c. Displacement, $\mathrm{h}=1.25 \mathrm{~m}$.

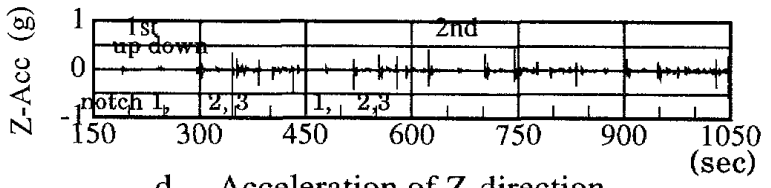

d. Acceleration of Z-direction.

Fig. 17. Change of value on up-down experiment.

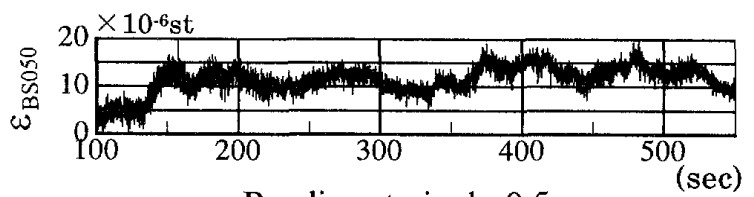

a. Bending strain, $\mathrm{h}=0.5 \mathrm{~m}$.

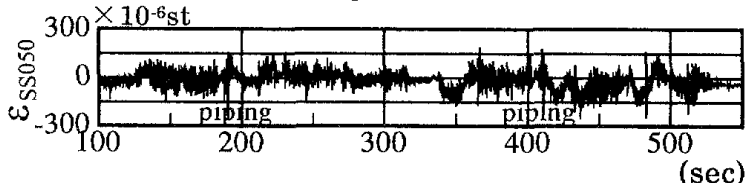

b. Stretching strain, $\mathrm{h}=0.5 \mathrm{~m}$.

(sec)

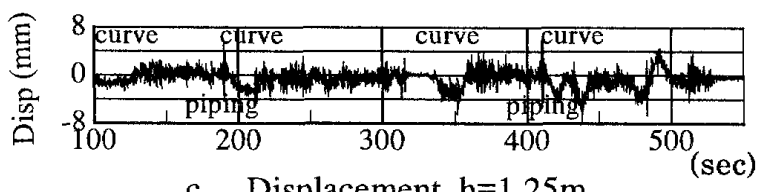

c. Displacement, $\mathrm{h}=1.25 \mathrm{~m}$.

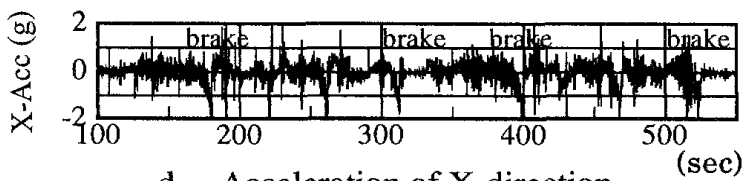

d. Acceleration of X-direction.

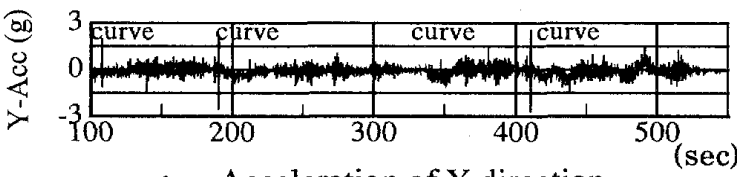

e. Acceleration of Y-direction.

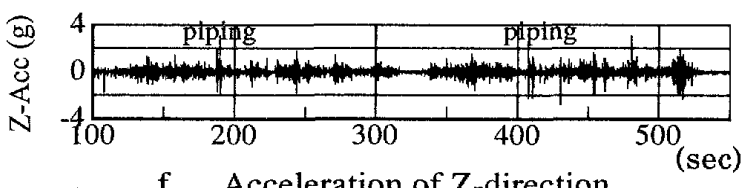

f. Acceleration of Z-direction.

Fig. 18. Change of value on circular experiment. 
$\mathrm{d} \sim \mathrm{e}$ の加速度（Xは後向きがプラス、右手系）波 形を見ると進行方向の速度変動を示す $\mathrm{d}$ の $\mathrm{X}$ 方向の 加速度に $1 \mathrm{~g}$ 近くの変動がある。また、 $\mathrm{f} の \mathrm{Z}$ 方向の 加速度は配管を乗り越えたと思われる 190 秒と 410 秒付近に変動を生じているが、全体的には小さく、e のY方向の加速度もスタート直後と反転時に旋回し た付近で変動を生じているが $0.05 \mathrm{~g}$ にも満たない。 そして、ひずみと壁面の変形は $\mathrm{X}$ 方向と $\mathrm{Y}$ 方向の加 速度に連動して変化しているが、変動量は $\mathrm{c}$ の壁面 の変形量で見ると $4 \mathrm{~mm}$ 前後の值を示し、静水圧に よる変形の $1 / 4$ 以下である。なお、変位計注左側面 につけてあるので右に旋回したときには遠心力が加 わって壁面が膨らみ、変位計との距離が狭まるので 信号はマイナス側に変動する。この際、加速度計は 右向きをプラスとしており、マイナス側に変動する 変化も見られる。

走行実験はヤード内で行ったもので、実走行を想 定すると速度や加・減速度も不十分であり、前後の 壁面に加わる荷重や変形等のデータも取得できてい ない。しかしながら、どのような変動を生じるかは 十分につかめ、この実験データを解析することであ る程度の推定は可能であり、有用である。また、船 舶に積載した場合には積み付け位置によって動摇振 幅や速度、加・減速度等が変化するが、これらが分 かれば適応も可能である。

\section{4. まとめ}

本研究ではコンテナと液体バッグの実機を使って 主に変形挙動を調べ、次の結果が得られた。

(1) 液体バッグを積載したときのコンテナ側壁面 の変形量がつかめ、コルゲーションの形状が均一な 台形で現行の 30ton 型と同一形状である中央付近の 最大変形量は $15 \mathrm{~mm} \sim 20 \mathrm{~mm}$ の範囲内であった。ま た、バッグから排水すると変形が回復することが確 認でき、運用のめどがついた。

（2）側壁をはりと仮定して変形量を試算した結果、 概ね妥当な值が得られたが、固定条件によって大き く変わるので、バッグの形状や接触状態、上下のサ イドレールの変形等も含めて調査する必要がある。

(3)コンテナヤード内での移動実験を行い、通常生 じる加速度や側壁の変形挙動等がつかめた。

\section{謝辞}

本研究は大井コンテナターミナルで実験を行い、 多数の皆様にご協力をいただきました。川㥓汽船の 柏木伸二氏、西尾秀明氏、小川テックの大岩要氏、 長田宗平氏、ダイトーコーポレーションの方々、他
関係各位に深く感謝いたします。

\section{参考文献}

（1）西野好生・久保雅義 : 袋体を用いた船舶による 液体輸送に関する基礎研究 $-\mathrm{IV}$. 一縮尺が異な る袋体の静的な相似性について一, 日本航海 学会論文集, 118 号, pp.45-252（2008）。

（2）JIS ハンドブック 鉄鋼 II - 2007，日本規格協 会 (2007).

(3) JIS ハンドブック 物流-2007，日本規格協会 (2007).

（4）吉野克一：コンテナを追え，成山堂 (2000).

（5）関西造船協会: 造船設計便覧 第 3 版, 海文堂 (1976).

\section{質疑応答}

亀岡福太郎（アイ・エイチ・アイ・マリンユナイテッド： 液体バッグを使用した方が専用タンクより有利 である点を教えてほしい。本研究のヤードトラッ ク実験は船に積載した時を模したものと考えるの か、実際の航海で働く応力はどのように見積もっ ているのか?

\section{三田重雄 :}

ご質問ありがとうございます。専用の液体タン クを用いた場合、空になったタンクを持ち帰る必 要があり費用がかかります。これに対し、使い捨 て式の液体バッグを使用した場合その必要はあり ません。また、液体バッグの製作費は専用タンク の製作費よりも安く、リサイクルが可能な樹脂を 材料にしているので輸送コストの削減だけではな く環境賁荷への低減もできます。

次に、ヤードトラックの実験ですが、あくまで も陸上輸送を対象として行っています。しかし、 カーブ切るときのデータは船が旋回するときのデ 一タとしても参考になりますので、まったく無関 係ではないと考えます。実際の航海で働く忘力は、 横摇れや旋回したときに側壁に働く荷重について ISO の傾斜水圧に関する基準があるとのことです が、どの程度見込め代良いのか検討しています。 笹健児 (広島商船専門高等学校)：

バッグ自体の強度はコンテナ自体の强度と比較 してどうですか?

\section{三田重雄 :}

バッグ本体のポリエチレンは水道管や灯油缶な どに使われており、実用上強度の問題はありませ ん。また、表面を覆っているポリプロピレンは一 般に見かけるアクリル樹脂や塩化ビニール樹脂と 
同程度でポリエチレンよりも強いです。コンテナ 本体は高耐候性の鋼で、バッグよりもはるかに強
度は高いです。現在、液体バッグの試験運用が行 われており、特に大きな問題は出ていません。 